\title{
Climatic Change \\ Potential consequences of projected climate change impacts on hydroelectricity generation \\ --Manuscript Draft--
}

\begin{tabular}{|c|c|}
\hline \multicolumn{2}{|l|}{ Manuscript Number: } \\
\hline Full Title: & $\begin{array}{l}\text { Potential consequences of projected climate change impacts on hydroelectricity } \\
\text { generation }\end{array}$ \\
\hline Article Type: & Toth Special Issue \\
\hline Corresponding Author: & $\begin{array}{l}\text { Pierre Mukheibir, PhD } \\
\text { Institute for Sustainable Futures, University of Technology Sydney } \\
\text { AUSTRALIA }\end{array}$ \\
\hline \multicolumn{2}{|l|}{$\begin{array}{l}\text { Corresponding Author Secondary } \\
\text { Information: }\end{array}$} \\
\hline Corresponding Author's Institution & Institute for Sustainable Futures, University of Technology Sydney \\
\hline \multicolumn{2}{|l|}{$\begin{array}{l}\text { Corresponding Author's Secondary } \\
\text { Institution: }\end{array}$} \\
\hline First Author: & Pierre Mukheibir, PhD \\
\hline \multicolumn{2}{|l|}{ First Author Secondary Information: } \\
\hline Order of Authors: & Pierre Mukheibir, PhD \\
\hline \multicolumn{2}{|c|}{ Order of Authors Secondary Information: } \\
\hline Abstract: & $\begin{array}{l}\text { There is a growing concern that countries should reduce their dependence on fossil } \\
\text { fuels for electricity generation and look to other cleaner technologies. Hydroelectricity is } \\
\text { one such option. However, given that hydropower is dependent on rainfall and } \\
\text { associated runoff for power generation, it is susceptible to both the positive and } \\
\text { negative impacts of climate change, such as increases in temperature and changes in } \\
\text { precipitation and runoff. In this paper, impacts on hydropower generation have been } \\
\text { organised as either changes in long-term trends or short-term variability and shocks. } \\
\text { These impacts could either manifest themselves as direct impacts on hydropower } \\
\text { generation potential or as indirect impacts (or ancillary impacts) such as increased } \\
\text { competition for water. Citing examples from around the world, this paper investigates } \\
\text { the scale of these projected impacts, and the potential cost implication of inaction. It } \\
\text { concludes by making recommendations for possible adaptive options to build resilience } \\
\text { in response to local impacts. }\end{array}$ \\
\hline \multirow[t]{4}{*}{ Suggested Reviewers: } & $\begin{array}{l}\text { Eric Williams } \\
\text { IAEA } \\
\text { E.Williams@iaea.org }\end{array}$ \\
\hline & $\begin{array}{l}\text { Jeannette Sieber } \\
\text { EUROPEAN INSTITUTE FOR ENERGY RESEARCH } \\
\text { Jeannette.Sieber@eifer.uni-karlsruhe.de }\end{array}$ \\
\hline & $\begin{array}{l}\text { Markku Rummukainen } \\
\text { Centre for Environmental and Climate Research (CEC) } \\
\text { Markku.Rummukainen@cec.lu.se }\end{array}$ \\
\hline & $\begin{array}{l}\text { Anthony Patt } \\
\text { International Institute for Applied Systems Analysis } \\
\text { patt@iiasa.ac.at }\end{array}$ \\
\hline
\end{tabular}


Potential consequences of projected climate change impacts on hydroelectricity generation

\author{
Pierre Mukheibir \\ Institute for Sustainable Futures, University of Technology Sydney, 235 Jones St, Ultimo, \\ Sydney, Australia \\ email: Pierre.Mukheibir@uts.edu.au \\ tel: +61295144962 \\ fax: +61295144941
}

\begin{abstract}
There is a growing concern that countries should reduce their dependence on fossil fuels for electricity generation and look to other cleaner technologies. Hydroelectricity is one such option. However, given that hydropower is dependent on rainfall and associated runoff for power generation, it is susceptible to both the positive and negative impacts of climate change, such as increases in temperature and changes in precipitation and runoff. In this paper, impacts on hydropower generation have been organised as either changes in long-term trends or short-term variability and shocks. These impacts could either manifest themselves as direct impacts on hydropower generation potential or as indirect impacts (or ancillary impacts) such as increased competition for water. Citing examples from around the world, this paper investigates the scale of these projected impacts, and the potential cost implication of inaction. It concludes by making recommendations for possible adaptive options to build resilience in response to local impacts.
\end{abstract}

Keywords: Hydropower, climate change, adaptation, runoff

\title{
1 Introduction
}

Projected climate change impacts due to fossil fuel combustion as an energy source pose considerable risk and uncertainty to the global economy (IPCC 2007a). In recent years, increasing attention has been given to hydropower. This is considered to be a renewable energy source but, in fact, is the one source of renewable energy that is most likely be affected by climate change, as it relies on rainfall-dependent runoff (Iimi 2007).

Electricity generation from hydropower contributes approximately $16 \%$ of global electricity generation (REN21 2011). In 2010 it produced three-quarters of all global renewable electricity. Large and small hydro contributed $70 \%$ and $6 \%$, respectively, with half the production coming from China, Brazil, the United States, Canada, and Russia (EIA 2010). In some countries, including Brazil and many African countries, $75 \%$ of grid electricity comes from hydro. The scale and growth of hydropower generation are discussed further in the Supplementary Material.

With a threefold increase in energy demand expected by 2100 , greenhouse gas concentrations look set to rise. Three major factors improve the attractiveness of renewable energy sources, including hydropower: a growing global demand for electricity, the likely increase in fossil fuel prices, and the need for clean energy sources. Hydropower production is thus expected to 
increase threefold over the next 100 years (Nakicenovic et al. 1998), mainly in Asia (led by China), Latin America (led by Brazil), and eastern Europe (Lehner et al. 2005).

Hydropower exploits resources that vary temporally, and this affects the reliability of the hydro energy supply. However, the controllable output provided by hydropower facilities that have storage can be used to meet peak electricity demands and help to balance out electricity systems that have large amounts of variable energy generation (IPCC 2011). Conventionally, hydropower potential is forecast based on the $90 \%$ dependable river flow (Jain and Singh 2003). However, changes in this flow due to climate change will alter the energy potential or even result in the operation becoming suboptimal where a plant is designed for a particular flow distribution (Iimi 2007). For example, in the past decade, hydroelectric plants in East African countries such as Kenya and Tanzania have been affected by drought, with resultant country-wide electricity shortages (Loisulie 2010).

This paper considers the potential impacts on hydropower from projected climate change, with specific reference to reduced runoff, increased runoff, increased average temperature, and increased peak temperature. Competition for water and the role of climate change in soil erosion are suggested as additional concerns that need to be taken into account when managing existing plants or siting new ones. Possible adaptive strategies are suggested, and the likely financial implications of inaction are presented. Illustrative case studies from around the world are cited throughout the paper.

For the purposes of this paper, the impacts of climate change on hydropower have been divided into two types, namely, direct and indirect impacts. Direct climate-induced impacts are those that directly affect the availability of water for generating power. Separating the impacts into climate change trends and extreme variability creates a clearer understanding of the impacts and associated vulnerabilities described in this paper, and will allow appropriate responses and management plans to be designed and implemented. Indirect impacts, on the other hand, are those that have a knock-on effect on hydropower.

\section{Potential impacts of climate change on hydroelectricity}

The fact that hydroelectricity harnesses the outputs of the local climate means that it may be at risk from changes in that climate. This paper will show that, although hydroelectricity is viewed as a mitigation measure, the hydroelectricity sector also needs to consider adaptation to climate change and extreme variability so that it can maintain its current levels of energy supply (see Fig. 1). When planning for new installations, the sector will also need to consider the impacts of climate change and extreme variability to ensure sound economic investments are made.

\section{< Figure 1 about here>}

Climate impacts have been documented as transforming the nature of surface water runoff through both climate variability and projected climate change impacts (IPCC 2007b). Impacts such as temperature increase, changes in mean annual precipitation, and variability in that precipitation (both seasonal and annual) thus have direct impacts on the availability of the hydropower supply. While the overall impact of climate change on global hydropower potential is expected to be slightly positive, the possibility of substantial variations across regions and even within countries is indicated (IPCC 2011). Most notably, the average potential is projected to somewhat decline in Europe (-0.16\%), and to somewhat increase in Asia $(0.27 \%)$ by 2050 (Hamududu and Killingtveit 2012).

$<$ Table 1 about here> 
In general, adaptive response measures fail to differentiate between the less predictable aspects of extreme climate variability and the more predictable gradual changes in climate trends, something which could lead to ineffectual responses. As noted above, to enable better response measures to be designed, climate change impacts have been discussed separately (as shown in Table 1), namely: those that manifest as:

- Trends with long-term consequences, and as

- Extreme variability that impacts in the short term.

The next section focuses on the first category.

\section{Long-term climate change trends}

As hydropower installations have long investment return periods, they are designed on the basis of an average historical climate, where rainfall fluctuates within a known envelope of variability, and hence an average generation capacity and output is usually expected. However, Milly et al. (2008) assert that, because of climate change, stationarity should no longer be the default assumption in water-resource assessment and planning. Changes in the design trend parameters could have either positive or negative consequences for the amount of electricity generated and for the returns on investment. It is therefore prudent for hydropower planners and managers to take projected changes in climate trends and variation into consideration.

Specifically, this paper considers changes in precipitation and temperature as the key drivers for the security of hydropower generation. These aspects are discussed further in this section.

\subsection{Reduction in average precipitation}

The sensitivity of river catchments to changes in precipitation increases on average with increases in catchment aridity (Riebsame et al. 1995). Work done by de Wit and Stankiewicz (2006) reveals that runoff amplifies the changes in precipitation, and that for example the magnitude of the run-off reduction is between 2-4 times greater than the reduction in the precipitation (Arnell 2004), depending on site-specific conditions.

Analysis conducted by Soils Incorporated (Pty) Ltd and Chalo Environmental and Sustainable Development Consultants (2000) revealed that a decline in annual runoff of 20$30 \%$ could reduce the amount of hydropower generated from the Kariba Dam to 56-71\% of normal operation. Similar results were obtained in studies conducted of hydroelectric power generation in the Zambezi Basin. Taken in conjunction with projections of future runoff, these studies indicate declining power production due to a significant reduction in river flows (Harrison and Whittington 2002; Riebsame et al. 1995). For the Nile Basin in North Africa, the multi-model average for reservoir simulations calculated by Beyene et al. (2010) showed that average energy production would remain unchanged for the first part of the $21^{\text {st }}$ century but that gradual reductions in hydropower generation would occur towards the latter part.

The following trends were observed from model runs for European hydropower installations (Lehner et al. 2005):

- Scandinavia and northern Russia experience an increase in their developed potential of $15-30 \%$, while the southwest and southeast show decreases of $20-50 \%$.

- The gross hydropower potential for the whole of Europe is projected to decline by about $6 \%$ by 2070 .

In California in the United States, it was shown that a small percentage change in rainfall can produce a much larger percentage change in runoff. For example, studies of the Colorado 
River suggest that an increase in temperature of $2^{\circ} \mathrm{C}$ and a $10 \%$ decline in precipitation could reduce the runoff by as much as $40 \%$, which in turn would have implications for hydropower generation (Kiparsky and Gleick 2003).

In South America, Brazil is the largest producer of hydroelectricity. Research conducted by de Lucena et al. (2009) in Brazil indicates that by the end of the $21^{\text {st }}$ century, total production could be reduced by $7 \%$ annually due to increasing temperatures, lower water flows, and variations in the precipitation regime.

A greater reduction in hydropower potential is anticipated in areas of Central America where river flows are expected to decline, such as in the Rio Lempa and the Simú-Caribbean basins (Maurer et al. 2008). Model results indicate that increased frequency of low-flow years will result in a decrease of 33-53\% in firm hydropower capacity by 2070-2099.

A modelling study conducted by Bari et al. (2005) on the impact of climate change on runoff in Western Australia revealed that for an $11 \%$ decrease in precipitation by 2050 , a $31 \%$ reduction in annual catchment yield would likely be experienced.

\subsection{Increase in average precipitation}

As hydropower installations are designed for a certain river flow, an increase in the flow due to climate change may not alter the energy generation capacity in real terms. In some cases plant operation may become suboptimal under altered flow conditions (Harrison and Whittington 2002). The installed capacity of a given plant is restricted by its storage and turbine capacity, which places limits on the amount of benefit that can be derived from higher flows.

However, in some cases the increased volume of water could allow for increased generation potential. Scenarios undertaken by various researchers indicate that in some parts of the world, there is potential for increased generation capacity because of increased runoff under projected climate change. For example, Mercier (1998) shows that for up to a $20 \%$ increase in annual precipitation in northern Quebec, Canada, an increase of up to $15 \%$ in annual power output could be achieved with existing plants. Riebsame et al. (1995) report that for a scenario with a similar increase in runoff, together with an average temperature increase of $4.7^{\circ} \mathrm{C}$, a $19 \%$ increase in power output could be expected on the Indus River in Pakistan. A study by Iimi (2007) for selected potential sites in India, Sri Lanka, and Vietnam reveal that as runoff had exceeded the 90 percentile dependable year, larger storage capacity could have economic benefits.

For high-elevation hydropower installations in California's Sierra Nevada, the projected shift in the centre of the hydrograph during the next hundred years will be to earlier in the year. Together with an increase in temperature, this will lead to a higher proportion of precipitation falling as rain rather than snow and earlier spring snow melt. Operations with low water storage capacity may suffer, as higher inflows in winter could increase spillage and hence reduce overall energy generation. The result will be a mismatch in timing between energy demand and energy generation (Vicuna et al. 2008).

Generally, an increase in precipitation is unlikely to have a negative impact on hydropower generation, and, depending on the location and catchment characteristics, some plants may see a slight increase in potential generation capacity. Some parts of the world are projected to become wetter under future scenarios (IPCC 2007b) and, with average runoff increasing, these areas could in future find hydropower generation a viable option. 


\subsection{Increase in average temperature}

An increase in the average temperature in a region has the potential to affect the runoff potential in a number of ways. In river catchments that rely on snowfalls, the projected increased temperatures will result in wetter precipitation, giving rise to more winter flows and reduced summer flows from ice thaws (Gleick 1998). Many regions depend on glacial melt for runoff. In the Andes, in South America, high temperature anomalies are causing the accelerated retreat of tropical glaciers (Ebinger and Vergara 2011). Scenarios project that glaciers in the eastern Rockies of Canada, for example, will melt substantially due to projected warmer temperatures. This may cause higher stream flows for the next 20-30 years, which would decrease thereafter because of the reduced glacial mass (Mercier 1998). Loss of natural storage in the form of snow and ice will require the construction of additional storage capacity in the catchment in future to maintain the hydropower generation potential.

Glacial retreat also negatively impacts the amount of snow that falls in winter, as is the case in the Himalayas (Bajracharya and Mool 2010), and this reduces potential runoff. A specific hazard related to glacial retreat is the formation of glacial lakes that eventually burst, an event known as a glacial lake outburst flood. The flooding to the downstream valley results in damage to infrastructure, including run-of-river hydropower installations (Government of Bhutan 2011).

Furthermore, higher average temperatures and/or extreme temperature variations have the potential to reduce the moisture content of the catchment soils. The combination of changes in precipitation, together with increased temperature, will affect the moisture levels of soil, which provides storage and regulates runoff. Drier soils absorb rainfall, thereby reducing the available runoff, while soils that are more saturated absorb less and thus increase the likelihood of flooding (Harrison and Whittington 2002).

More commonly, increasing temperatures result in an increase in potential evaporation; given that temperatures are projected to increase globally, evaporation on large open waters can be expected to increase. Changes in other meteorological controls, such as wind speed and humidity, may exaggerate or offset the rise in temperature. Changes in humidity have a retarding effect on the rate of evaporation (IPCC 2001).

Evaporation losses per annum have been calculated to be on average 1.1 meters of depth. This could be much higher depending on the climate of the region. For example, this depth of loss for the Aswan High Dam on the Nile River is $2.7 \mathrm{~m}$ or $11 \%$ of the reservoir capacity (Gleick 1994). A study conducted in California showed that hydroelectric facilities have average evaporative losses of $5.4 \mathrm{~m}^{3}$ of water per $10 \mathrm{MWh}$ electricity produced (Gleick 1994). Deep dams with smaller surface areas would be less affected than those with large surface areas.

\section{Increase in extreme climate variability}

Hydropower plants currently have to operate under climate variability, which, as the previous examples have shown, will make ensuring energy security under increased climate variability and extreme events even more difficult. Variability that is of concern comes from drought and flooding. Variations and extremes in temperature will not directly affect the average supply of electricity.

\subsection{Drought}

The direct impact of reduced precipitation, either in average or seasonal terms, is that the runoff is reduced, with, consequently, a negative effect on water storage in dams. Depending on the duration of the reduced precipitation, it may be possible for storage-based hydropower 
plants to manage their storage and maintain their normal generation of electricity over the duration of the drought. The same is not true of run-of-river installations, which depend on the designed run-of-river flow to be able to maintain their electricity output. Without buffering storage, they are more susceptible to short-term changes in runoff.

Changes in electricity generation due to reduced precipitation can be illustrated by examples of drought from Africa, which in the past have caused some interruptions in hydropower generation. Electricity rationing has been an ongoing occurrence in Tanzania, with, for example, the hydroelectric plants being operated in 2006 at only $30 \%$ capacity, and sometimes falling as low as $10 \%$ in the same year because of drought (Loisulie 2010). More recently, in 2011 Tanzania was forced to ration electricity as the hydroelectric plants had been affected by persistent drought (BBC 2011). In Zimbabwe, the Kariba Dam contributes $50 \%$ of the country's electricity needs, but in 1992 generation dropped by $8 \%$ due to drought (Chenje and Johnson 1996).

\subsection{Flooding}

There are limits to the amount of gain that can be achieved from a sudden increase in the runoff due to variations in average rainfall patterns. Run-of-river facilities would not have the turbine capacity to accommodate sudden and irregular increases in runoff. As storage-based facilities are often allowed to spill, they do not yield any additional electricity.

In some instances, increased intensity and frequency of storms, floods, and heavy precipitation can adversely affect hydropower plants (Mideksa and Kallbekken 2010). Unexpected flooding can be detrimental to large dams where the large loads of sediments carried by the rivers settle in the dams and lakes. At in-stream hydro plants, large logs and vegetation can cause damage or block up the system.

\section{Indirect climate change impacts}

In addition to the direct climate change-induced impacts, ancillary or indirect impacts will also come into play. Two key impacts in this regard are, first, the increased future water scarcity due to changes in rainfall regimes, and second, the fact that its effects on land use changes and land degradation will determine siltation levels.

\subsection{Water scarcity}

Hydropower normally competes for licensed bulk entitlements with other end users, such as irrigated agricultural, industrial, and urban water demands, together with ecosystem needs. To complicate things further, river catchments are often shared among countries. Under a reduced precipitation scenario, water scarcity is set to increase this tension, with the need to provide food and sufficient potable water for local populations and commercial markets competing with the commercial viability of the hydropower companies (Hove et al. 2011).

Evapotranspiration by natural vegetation and crops can be expected to increase with a rise in average temperature or more frequent extremes within a catchment (Mimikou and Baltas 1997). This has the potential to decrease the runoff and also increase the amount of water needed for irrigation, which will further exacerbate the tension within the catchment around the issue of rights to water and allocation arrangements.

\subsection{Siltation through land degradation}

Siltation refers to the deposition of particles of the river load. Siltation is the consequence of erosion where rains, and consequently rivers, can be aggressive. Non-existent or sparse vegetation and the desiccation of soils during dry seasons can make the soils particularly 
vulnerable to the water action. The slowing of the river flow by dam walls causes the river to deposit its silt load and thereby reduce the operational life of the dam and hydroelectricity facility.

Poor catchment management, especially in developing countries, through the over-cultivation of steep slopes and overgrazing, has led to increased erosion (Hove et al. 2011). This, together with the drying of catchments due to increased temperature and increasingly variable precipitation, has the potential to increase the erosion of the catchment and hence, in turn, increase the siltation load of the river.

\section{Economic implications}

Hydropower is currently one of the lowest-cost energy technologies, with between 3-12 cents per kWh for capacities greater than $1 \mathrm{MW}$ (as shown in Table 2), followed by wind generation (REN21 2011). As hydropower is characterized by high capital costs and relatively low operating costs, the capital investment return period is often significantly longer than for other types of energy generation plants.

\section{$<$ Table 2 about here>}

Studies by Harrison et al. $(2003,2006)$ indicate that there is a real risk to financial returns for investments in hydropower plants due to projected climate change impacts. They found that under various climate scenarios, there were increases in the variance of the financial returns. Results from their analysis of the Batoka Gorge hydropower plant (1600MW) showed that for a scenario with a $10 \%$ decrease in annual runoff, the net present value (NPV) for the project fell by more than 60\% (Harrison and Whittington 2002). The NPV became negative for scenarios with even greater decreases in runoff. This analysis, though location-specific, has relevance for future hydropower investment planning.

This trend was confirmed in a study in Quebec, Canada, where the cost of inaction was found to be higher than the cost of the recommended adaptive responses. The impacts on a hydropower system were mapped under a number of different future hydrological conditions for a business-as-usual scenario and for a scenario where adaptive measures were taken. The results indicated that the price of inaction was a $14 \%$ reduction in power output, while the adaptive scenario yielded a $15 \%$ increase in output (Minville et al. 2009).

In an earlier study of Canada, it was estimated that a reduction of $0.5 \mathrm{~m}$ to $1.0 \mathrm{~m}$ in the levels of the Great Lakes would result in a loss of hydropower capacity of around $20 \%$, equivalent to $\$ 111$ million in lost revenue (Mercier 1998).

During a multiyear drought in California between 1987 and 1991, decreased hydropower generation led to increases in fossil-fuel combustion and higher costs to consumers of more than $\$ 3$ billion, as well as increased greenhouse gas emissions (Kiparsky and Gleick 2003).

\section{Potential adaptive responses}

In response to the climate-induced impacts described above, there are various kinds of adaptive measures that can reduce vulnerability and increase resilience for hydropower: these can be differentiated based on the following attributes (Ebinger and Vergara 2011; Williamson et al. 2009):

- A proactive approach aims to reduce exposure to risks by building adaptive capacity by first, improving information on climate change impacts on hydropower production (Minville et al. 2009) for decision making and by second, incorporating climate risks into hydropower management and operational decisions. 
- In contrast, a reactionary approach responds to extreme weather-related service interruptions by reinforcing existing energy infrastructure, such as raising a dam wall to enable greater water storage. However, depending on the specific circumstances, a more appropriate response may be to change the operating regime to accommodate the change of circumstance.

- A short-term response to climate variability can be viewed as tactical or operational adjustments, such as allowing the storage to spill during a higher than normal runoff. However, a long-term response can be viewed as strategic adaptation and may include options such as regional integration through capital-intensive transmission pipelines.

- Localised adaptation measures focus on specific hydropower infrastructure, whereas systemic measures would consider the flexibility and diversity of the energy sector as a whole. Erosion prevention in a catchment would be viewed as a local response. A systemic approach would entail the consideration of a variety of different energy sources across a range of climatic and geographical regions.

- Adaptation decisions can be made by private enterprises and are considered to be autonomous and to respond to market forces, while decisions made by government or the public sector are policy-driven. The location of specific hydropower installations, for example, may be chosen to satisfy regional developmental objectives and not purely for profit motives.

- Adaptive actions to reduce risks and potential generation losses can be classified as either technical or behavioural. Technical responses include those measures that are structural in nature and result in a physical change to the infrastructure, such as raising a dam wall to increase the storage. Changing the operating rules or water allocations would be considered behavioural changes.

Adaptation strategies that plan for the variability in today's climate as well as future climate changes can be viewed as no-regrets options and would include the following:

A) Improved climate change knowledge and information:

Studies have shown that precipitation is the most important source of uncertainty derived from the Global Circulation Model predictions, and that this uncertainty is further magnified by runoff-related issues. The historical practice of depending on natural systems to fluctuate within an unchanging envelope of variability is no longer appropriate (Milly et al. 2008). Therefore, improved skill in forecasting precipitation has the potential to greatly improve decision making (Markoff and Cullen 2008). This requires proactive monitoring of the regional and local climate and catchment runoff to provide improved and reliable historical data at a scale that is useful and relevant. In addition, the integration of climate risks into the operational and management decision-making process will ensure a proactive approach (Ebinger and Vergara 2011). This information will improve the early warning systems that include procedures both for evacuation and for securing the electricity generation installation and transmission lines before the extreme weather event occurs (Urban and Mitchell 2011).

To understand the impacts, a distinction should therefore be made between trends and extreme variability (shocks). Characterising these factors as either trends or extremes provides two key benefits. First, the different impacts on the hydropower infrastructure can be distinguished and therefore more clearly assessed; second, appropriate responses can be identified to manage the different impacts and provide flexible adaptive capacity, as well as being robust to shocks (see Table 1). Climate change trends and extreme variability need to be considered when siting new plants and when undertaking associated feasibility studies and environmental impact assessments (Urban and Mitchell 2011). 
If power generation equipment is designed to operate optimally over the range of climate conditions that could reasonably be expected for the lifespan of the hydropower plant, the facility will be better able to cope with current variability and also with future changes.

Adoption of an incremental approach to improving infrastructure, will allow responses, such as raising the dam wall or constructing further run-of river plants in a catchment, to be made as and when new and improved information becomes available (Cervigni and Robinson 2011). Altering the scale and timing of planned projects based on this approach will allow for an adaptation policy that incorporates a contingency management approach. It will avoid incurring large capital expenditures that may not be required or that respond to the wrong signal.

In the case of aging infrastructure, there will be an opportunity to reinvest in older plants needing refurbishment and modernisation. This will be a win-win scenario where upgrading of these plants will enable long-term sustainability of important energy resources and infrastructure, while also adapting to climate change impacts.

The further construction of berms and swales in the upstream catchment can not only reduce localised soil erosion in the catchment and siltation of the hydropower storage facility, but also reduce the flooding potential in a catchment (Mukheibir 2007).

C) Catchment management and water allocation:

As discussed in Section 5.1, competition for water will probably grow under reduced precipitation trends. The competing demands for water may also result in a reduced allocation in future to the hydropower companies in favour of satisfying basic human needs such as potable water and food security. Other primary industries such as agriculture may also take precedence. These conditions should be set out in licensing and bulk water allocation arrangements to avoid conflict under a projected scenario such as this (Hove et al. 2011). The development of drought management plans would assist in allocations between multiple water users in the event of shortfalls in supply. In addition, catchment management policies should consider appropriate land-use management practices that minimise soil erosion in the catchment, thereby avoiding downstream implications.

D) Diversifying the energy mix:

Conjunctive operation with other diverse energy sources through renewable energy trading is a means of reducing reliance on hydropower in a changing environment (Williamson et al. 2009). However, this may not always provide sufficient diversity or be spatially possible, and further reliance on fossil fuel-based technologies for diversity may be required. Diversity could also be encouraged through the regional integration of the electricity grid and transmission pipelines between plants and catchments. Inextricably linked to supply diversification is the implementation of demand-side management, which has been shown to be a useful adaptive management tool during times of energy supply variability and high peak demand periods (Williamson et al. 2009). This, together with water efficiency measures, would reduce overall demand for the available water in the catchment.

\section{Conclusions}

To design and manage a resilient hydropower system, it is necessary to identify the factors that may change in the future, specifically those that have a material impact on ensuring hydropower security - that is, those with high levels of uncertainty and high significance to the performance of the installation. A robust methodology is therefore required to assess the 
threat that climate change poses to existing installations and potential hydropower investment.

There is thus a growing need for further information and research at the local and regional level so that the linkages between hydropower infrastructure, water resources, and climate change, including extreme events, can be better understood. Improved confidence levels are needed in the results of the climate and runoff projections so that planners will trust and consider their implications without having to integrate wide-ranging scenarios.

Unfortunately, as adaptation planning for climatic impacts in the hydropower field is still relatively new, there are comparatively few examples of adaptation and associated costs in the published literature. It would be prudent, therefore, for the projected changes in the hydrological regimes to be accounted for in future hydropower management strategies and plans.

\section{References}

Arnell NW (2004) Climate change and global water resources: SRES emissions and socioeconomic scenarios. Glob Environ Change 14(1):31-52. doi: 10.1016/j.gloenvcha.2003.10.006

Bajracharya S, Mool P (2010) Glaciers, glacial lakes and glacial lake outburst floods in the Mount Everest region, Nepal. Ann Glaciol 50(53):81-86. doi: $10.3189 / 172756410790595895$

Bari MA, Berti ML, Charles SP, Hauck EJ, Pearcey M (2005) Modelling of streamflow reduction due to climate change in Western Australia - A case study. In International Congress on Modelling and Simulation, December 12-15 2005, Melbourne, Australia

BBC (2011) East Africa drought: Power cuts in Tanzania. BBC News. http://www.bbc.co.uk/news/world-africa-14192896. Accessed 4 May 2013

Beyene T, Lettenmaier D, Kabat P (2010) Hydrologic impacts of climate change on the Nile River Basin: implications of the 2007 IPCC scenarios. Clim Change,100(3):433-461. doi: 10.1007/s10584-009-9693-0

Callaway JM (2004) Adaptation benefits and costs: are they important in the global policy picture and how can we estimate them? Global Environ Change 14, 273-282. doi: 10.1016/j.gloenvcha.2004.04.002

Cervigni R, Robinson S (2011) The cost of adapting to climate change in Ethiopia: Sectorwise and macro-economic estimates. In the 18th Meeting of the European Association of Environmental and Resource Economists, June 29-July 2 2011, Rome, Italy

Chenje M, Johnson P (1996) Water in Southern Africa. Environment and Land Management Sector Coordination Unit, Southern African Development Community, Maseru, Lesotho and the International Union for Conservation of Nature, Harare, Zimbabwe

de Lucena AFP, Szklo AS, Schaeffer R, de Souza RR, Borba BSMC, da Costa IVL et al. (2009) The vulnerability of renewable energy to climate change in Brazil. Energy Policy, 37(3):879-889. doi: 10.1016/j.enpol.2008.10.029 
de Wit M, Stankiewicz J (2006) Changes in surface water supply across Africa with predicted climate change. Sci 311:1917-1921. doi: 10.1126/science.1119929

Ebinger J (2010) Albania's Energy Sector: Vulnerable to Climate Change. World Bank, Washington, DC

Ebinger J, Vergara W (2011) Climate Impacts on Energy Systems: Key Issues for Energy Sector Adaptation. World Bank, Washington, DC

EIA (2010) International Energy Annual 2006: Electricity Generation. US Department of Energy. http://www.eia.gov/cfapps/ipdbproject/iedindex3.cfm?tid=6\&pid=33\&aid=12\&cid=al 1,\&syid=2007\&eyid=2011\&unit=BKWH. Accessed 3 May 2013

Gleick P (1994) Water and energy. Annual Rev Energy Environ 19:267-299. doi: 10.1146/annurev.eg.19.110194.001411

Gleick P (1998) Water planning and management under climate change. Water Resour Update 112:25-32

Government of Bhutan (2011) Securing the natural freshwater systems of the Bhutan Himalayas: White Paper. India Environment Portal. http://sa.indiaenvironmentportal.org.in/files/file/Water_Paper_Bhutan.pdf. Accessed 6 May 2013

Hamududu B, Killingtveit A (2012) Assessing climate change impacts on global hydropower. Energ 5(2):305-322. doi: 10.3390/en5020305

Harrison GP, Whittington HW (2002) Susceptibility of the Batoka Gorge hydroelectric scheme to climate change. J Hydrol 264:230-241. doi: 10.1016/S00221694(02)00096-3

Harrison G, Whittington H, Wallace A (2003) Climate change impacts on financial risk in hydropower projects. IEEE Trans Power Syst 18(4):1324-1330. doi: 10.1109/TPWRS.2003.818590

Harrison G, Whittington H, Wallace A (2006) Sensitivity of hydropower performance to climate change. Int J Power Energy Syst 26(1): 42-48. doi: 10.2316/Journal.203.2006.1.203-3390

Hove H, Parry J-E, and Lujara N (2011) Maintenance of hydropower potential in Rwanda through ecosystem restoration. World Resources Report, Washington DC

IEA (1998) World Energy Outlook 1998. International Energy Agency, Paris

Iimi A (2007) Estimating Global Climate Change Impacts on Hydropower Projects: Applications in India, Sri Lanka and Vietnam. World Bank, Washington, DC

IPCC (2001) Climate Change 2001: Impacts, adaptation and vulnerability. Cambridge University Press, Cambridge and New York

IPCC (2007a) Summary for policymakers. In: Metz B, Davidson OR, Bosch PR, Dave R, Meyer LA (eds) Climate Change 2007: Mitigation of Climate Change. Contribution 
of Working Group III to the Fourth Assessment Report of the Intergovernmental Panel on Climate Change. Cambridge University Press, Cambridge and New York, pp $1-23$

IPCC (2007b) Summary for policymakers. In: Parry ML, Canziani OF, Palutikof JP, van der Linden PJ, Hanson CE (eds) Climate Change 2007: Climate change impacts, adaptation and vulnerability. Contribution of Working Group II to the Fourth Assessment Report of the Intergovernmental Panel on Climate Change. Cambridge University Press, Cambridge and New York, pp 7-22

IPCC (2011) Special report on Renewable Energy Sources and Climate Change Mitigation. Cambridge University Press, Cambridge and New York

Jain SK, Singh VP (2003) Water resources systems planning and management. Elsevier, Amsterdam

Kiparsky M, Gleick P (2003) Climate Change and California Water Resources: A Survey and Summary of the Literature. Pacific Institute for Studies in Development, Environment, and Security, Oakland, California

Lehner B, Czisch G, Vassolo S (2005) The impact of global change on the hydropower potential of Europe: a model-based analysis. Energy Policy, 33(7):839-855. doi: 10.1016/j.enpol.2003.10.018

Loisulie S (2010) Vulnerability of Tanzania hydropower production to extreme weather events. In the Joint ICTP-IAEA Workshop on Vulnerability of Energy Systems to Climate Change and Extreme Events, April 19-23 2010, Trieste, Italy

Markoff M, Cullen A (2008) Impact of climate change on Pacific Northwest hydropower. Clim Change 87:451-469. doi: 10.1007/s10584-007-9306-8

Maurer E, Adam JC, Wood AW (2008) Climate model based consensus on the hydrologic impacts of climate change to the Rio Lempa basin of Central America. Hydrol Earth Syst Sci Discuss 5:3099-3128. doi: 10.5194/hessd-5-3099-2008

Mercier G (1998) Canada country study: Climate impacts and adaptation: Energy Sector. In: Koshida G and Avis W (eds) Canada Country Study: Climate Impacts and Adaptation: National sector volume. Environment Canada, Toronto

Mideksa TK, Kallbekken S (2010) The impact of climate change on the electricity market: A review. Energy Policy 38(7):3579-3585. doi: 10.1016/j.enpol.2010.02.035

Milly P, Betancourt J, Falkenmark M, Hirsch R, Kundzewicz Z, Lettenmaier D et al. (2008) Stationarity is dead: Whither water management. Sci 319:573-574. doi: 10.1126/science. 1151915

Mimikou M, Baltas E (1997) Climate change impacts on the reliability of hydroelectric energy production. J Hydrol Sci 42(5):661-678. doi: 10.1080/02626669709492065

Minville M, Krau S, Brissette F, Leconte R (2009) Behaviour and performance of a water resource system in Quebec (Canada) under adapted operating policies in a climate change context. Water Resour Manag 24(7):1333-1352. doi: 10.1007/s11269-009$9500-8$ 
Mukheibir P (2007) Possible climate change impacts on large hydroelectricity schemes in Southern Africa. J Energy South Afr 18(1):4-9

Nakicenovic N, Grübler A, McDonald A (1998) Global energy perspectives. Cambridge University Press, Cambridge and New York

REN21 (2011) Renewables 2011 Global Status Report. REN21 Secretariat, Paris

Riebsame WE, Strzepek KM, Wescoat Jr. JL, Perrit R, Graile GL, Jacobs J et al. (1995) Complex river basins. In: Strzepek KM and Smith JB (eds) As Climate Changes, International Impacts and Implications. Cambridge University Press, Cambridge, pp $57-91$

Soils Incorporated (Pty) Ltd, Chalo Environmental and Sustainable Development Consultants (2000) Kariba Dam Case Study. World Commission on Dams, Cape Town, South Africa

Urban F, Mitchell T (2011) Climate change, disasters and electricity generation: Strengthening Climate Resilience: Discussion Paper 8. Institute of Development Studies, Brighton, United Kingdom

Vicuna S, Leonardson R, Hanemann M, Dale L, Dracup J (2008) Climate change impacts on high elevation hydropower generation in California's Sierra Nevada: a case study in the Upper American River. Clim Change 87(Suppl 1):S123-S137. doi: $10.1007 / \mathrm{s} 10584-007-9365-\mathrm{x}$

WCD (2000) Dams and development: A new framework for decision-making. Earthscan Publications, London

Williamson LE, Connor H, Moezzi M (2009) Climate-proofing energy systems. Helio International, Paris 
Table 1 Responses to future uncertainty.

1 
Table 2 Average cost of hydropower in 2010 (REN21 2011).

1

2

3

4

5

6

7

8

9

10

11

12

13

14

15

16

17

18

19

20

21

22

23

24

25

26

27

28

29

30

31

32

33

34

35

36

37

38

39

40

41

42

43

44

45

46

47

48

49

50

51

52

53

54

55

56

57

58

59

60

61

62

63

64

65

\begin{tabular}{|c|c|c|}
\hline Hydro Plant size & Capacity & Cost $(\$ / K W h$ \\
\hline Large & $10 \mathrm{MW}-18,000 \mathrm{MW}$ & $0.03-0.05$ \\
\hline Small & $1 \mathrm{MW}-10 \mathrm{MW}$ & $0.05-0.12$ \\
\hline Mini- & $100 \mathrm{~kW}-1,000 \mathrm{~kW}$ & $0.05-0.12$ \\
\hline Micro- & $1 \mathrm{~kW}-100 \mathrm{~kW}$ & $0.07-0.30$ \\
\hline Pico- & $0.1 \mathrm{~kW}-1 \mathrm{~kW}$ & $0.20-0.40$ \\
\hline
\end{tabular}


Fig. 1 Two-way interaction between energy supplies and climate change 
Supplementary Material
Click here to download S

Click here to download Supplementary Material: Mukheibir_Hydro_8_Supplement.pdf

entary Material: Mukheibir_Hydro_8_Supplement.pdf

$(2$

entary Material: Mukheibir_Hydro_8_Supplement.pdf

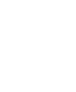

.

\author{
$\sqrt{10}$
}

$\sqrt{3}$

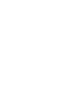

(2)

$\sqrt{2}$

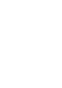

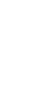

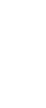

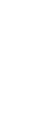

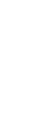

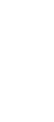

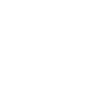
更

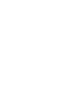

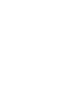

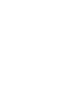
更

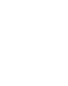

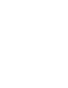
更

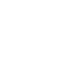
更

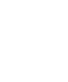

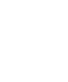
更

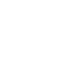

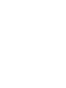

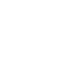
更

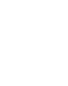
(1) (1) (1) (1) 